\title{
PENERAPAN KONSEP TEORI PERMAINAN (GAME THEORY) DALAM PEMILIHAN STRATEGI KAMPANYE POLITIK (Studi Kasus : Strategi Pemenangan Pemilukada DKI Jakarta Tahun 2017)
}

\author{
Ahmad Saifuddin $^{1 \S}$, Ni Ketut Tari Tastrawati ${ }^{2}$, Kartika Sari ${ }^{3}$ \\ ${ }^{1}$ Jurusan Matematika; Fakultas MIPA - Universitas Udayana [Email: saifsubandi@gmail.com] \\ ${ }^{2}$ Jurusan Matematika, Fakultas MIPA - Universitas Udayana [Email:taritastrawati@yahoo.com] \\ ${ }^{3}$ Jurusan Matematika, Fakultas MIPA - Universitas Udayana [Email:sarikaartika@unud.ac.id] \\ ${ }^{\S}$ Corresponding Author
}

\begin{abstract}
In Game Theory, generally discusses the zero sum games and non-zero sum games. Both of these studies applied in solving problems predicting the chosen decision based capabilities (pay off). In a case study of the preparation and delivery of the election in Jakarta through the application of the concept of the non-zero sum game obtained by the conclutions that $A H Y-S M$ and $A B-S U$ has five same optimum strategies: capture East Jakarta voters, women voters, 20 -29 years old voters, graduated from high school voters, and the Javaness community. While BTP - DSH only different in maximizing strategy of capturing men voters and West Jakarta voters.
\end{abstract}

Keywords: Game Theory, political, election

\section{PENDAHULUAN}

Setelah ditetapkan pasangan calon gubernur dan wakil gubernur yang akan bersaing di pemilukada DKI Jakarta 2017, yakni AHY SM, BTP - DSH, dan AB - SU (disamarkan), tentu upaya pemenangan calon (kampanye) dari masing-masing pasangan akan semakin gencar dilakukan. Kampanye tidak hanya dilakukan oleh pasangan calon itu sendiri namun juga dukungan dari koalisi yang mendukungnya. Tentu hal tersebut membutuhkan pemikiran yang logis dan matang untuk menentukan strategi yang optimal sehingga keputusan yang diambil bisa menguntungkan pasangan calon. Salah satu metode dalam merumuskan dan memutuskan strategi terbaik yang bisa digunakan dalam pemilihan strategi kampanye pada pemilukada adalah dengan Teori Permainan atau Game Theory.

Teori Permainan adalah ilmu pengetahuan berupa teori matematis yang digunakan untuk menentukan, merumuskan, dan mempelajari situasi konflik atau kompetisi yang melibatkan dua atau lebih pihak guna mendapatkan suatu keputusan yang optimal bagi setiap pihak (Hendri, 2009). Teori Permainan dapat juga didefinisikan sebagai suatu teknik yang digunakan untuk menganalisis situasi di mana dua atau lebih individu atau lembaga hasil dari suatu tindakan salah satu dari mereka tidak hanya bergantung pada tindakannya sendiri tetapi juga pada tindakan yang diambil oleh individu atau lembaga lain. Dalam keadaan ini rencana strategi individu yang besangkutan akan bergantung pada harapan tentang apa yang individu lain lakukan (Charmichael, 2005).

Dalam teori permainan, para pemain memanfaatkan teknik matematika dan pemikiran logis agar sampai pada kemungkinan strategi terbaik dalam pengambilan keputusan untuk memenangkan persaingan. Strategi optimal dapat dilihat dari nilai pay off (nilai yang bisa diharapkan dari hasil penggunaan strategi) yang optimal. Maksudnya, penggunaan strategi dapat memberikan keuntungan yang maksimal atau kerugian yang minimal setelah permainan selesai. 
Penelitian terkait mengenai aplikasi konsep teori permainan dalam pengambilan keputusan politik telah dilakukan dengan studi kasus strategi pemenangan pemilukada Jawa Barat tahun 2013 oleh partai politik. Peneliti menggunakan konsep 2-person non zero sum game dengan data hasil survei elektabilitas yang dirilis selama masa kampanye. Hasil dari penelitian tersebut menunjukkan bahwa dengan teori permainan, pasangan calon disarankan memfokuskan strategi tertentu untuk menjaring suara optimal. Pasangan A disarankan memfokuskan pada pelaksanaan strategi pencitraan dan melakukan strategi penjaringan pemilih dari kalangan pemilih mengambang. Pasangan B disarankan menfokuskan pada strategi pencitraan dan penjaringan pemilih dari kalangan loyal (Mustaqim, 20013).

Melihat penelitian tersebut, penulis tertarik untuk melakukan penelitian mengenai penerapan teori permainan dalam pemilihan strategi kampanye politik dengan studi kasus strategi pemenangan pemilukada DKI Jakarta tahun 2017 dengan menggunakan konsep 3-person non zero sum game untuk menentukan keputusan optimal dari ketiga pasangan calon.

Tujuan dari penelitian ini adalah:

1. Mengetahui ekspektasi nilai hasil penggunaan strategi (expected pay off) dari ketiga pasangan calon pada pemilukada DKI Jakarta tahun 2017 menggunakan teori permainan.

2. Mengetahui strategi ketiga pasangan calon pada pemilukada DKI Jakarta tahun 2017 untuk memperoleh suara maksimal menggunakan konsep teori permainan.

Selanjutnya akan dijelaskan konsep-konsep yang digunakan dalam teori permainan untuk menghasilkan suatu keputusan yang optimal.

Dalam teori permainan, setiap pemain akan memperoleh keuntungan atau kerugian dari setiap strategi yang digunakannya. Keuntungan atau kerugian yang diperoleh dapat dilihat dari pay off masing-masing strategi pemain. Pay off dalam suatu permainan menyatakan ukuran seberapa bagus pemain dalam melakukan suatu permainan (Charmichael, 2013). Pay off - pay off tersebut disajikan dalam suatu matriks yang disebut sebagai matriks pay off. Pada penelitian ini digunakan konsep 3-person games sehingga bentuk umum matriks pay off yang digunakan adalah seperti matriks (1) di bawah ini (Ririez, 2011):

$$
\begin{aligned}
& \left.\begin{array}{cccc}
A_{1} & C_{1} & \ldots & C_{k} \\
B_{1} & {\left[\left(a_{111}, b_{111}, c_{111}\right)\right.} & \ldots & \left(a_{11 k}, b_{11 k}, c_{11 k}\right) \\
\vdots & \vdots & \ddots & \vdots \\
B_{j} & \left(a_{1 j 1}, b_{1 j 1}, c_{1 j 1}\right) & \ldots & \left(a_{1 j k}, b_{1 j k}, c_{1 j k}\right)
\end{array}\right] \\
& \left.\begin{array}{cccc}
A_{i} & C_{1} & \ldots & C_{r} \\
B_{1} & {\left[\left(a_{i 11}, b_{i 11}, c_{i 11}\right)\right.} & \ldots & \left(a_{i 1 k}, b_{i 1 k}, c_{i 1 k}\right) \\
\vdots & \vdots & \ddots & \vdots \\
B_{n} & \left(a_{i j 1}, b_{i j 1}, c_{i j 1}\right) & \ldots & \left(a_{i j k}, b_{i j k}, c_{i j l}\right)
\end{array}\right] \\
& \text { Pada matriks di atas, } a_{i j k}
\end{aligned}
$$

menginterpretasikan pay off bagi pemain A saat dia menggunakan strategi $A_{i}$, pemain $\mathrm{B}$ menggunakan strategi $B_{j}$, dan pemain $\mathrm{C}$ menggunakan strategi $C_{k}$, untuk $i=1, \ldots, r ; j=1$, $\ldots, s ; k=1, \ldots, t$.

Untuk menentukan nilai pay off pada permainan dengan 3 pemain dapat menggunakan rumus sebagai berikut [6]:

$\begin{aligned} a_{i j k} & =A_{i}-\operatorname{maks}\left(B_{j}, C_{k}\right) \\ b_{i j k} & =B_{j}-\operatorname{maks}\left(A_{i}, C_{k}\right) \\ c_{i j k} & =C_{k}-\operatorname{maks}\left(A_{i}, B_{j}\right)\end{aligned}$

Dalam teori permainan, strategi terbaik (optimal) dapat ditentukan dengan konsep Ekuilibrium Nash. Ekuilibrium Nash atau disingkat ekuilibrium adalah kombinasi strategi pemain sehingga strategi tersebut adalah strategi terbaik bagi masing-masing pemain. Dengan kata lain, ekuilibrium Nash adalah kondisi dimana satu pihak mengambil keputusan berdasarkan keputusan yang diambil pihak lain sehingga semua pemain memainkan strategi ekuilibrium (Septiyani, 2007).

\section{METODE PENELITIAN}

Penelitian ini menggunakan data sekunder, yaitu hasil kuesioner Media Survei Indonesia (Median) yang dirilis pada 6 Februari 2017. Pengolahan data pada penelitian ini dibantu dengan menggunakan Software Microsoft Excel.

Langkah-langkah untuk menyelesaikan permainan tersebut adalah sebagai berikut:

1. Mengumpulkan data

2. Membuat matriks pay off dari data survei. 
3. Memeriksa keberadaan ekuilibrium Nash.

i. Jika terdapat ekuilibrium murni Nash, maka ditentukan strategi optimum setiap pemain.

ii. Jika tidak terdapat ekuilibrium murni Nash:

a. Mereduksi matriks pay off jika memungkinkan, menggunakan konsep dominasi.

b. Membentuk persamaan ekspektasi pay off .

c. Menentukan nilai ekspektasi pay off bagi masing-masing calon menggunakan konsep ekuilibrium Nash.

d. Menentukan strategi optimal bagi masing-masing calon berdasarkan nilai ekspektasi pay off yang telah diperoleh.

\section{HASIL DAN PEMBAHASAN}

\subsection{Pengolahan Data dan Perhitungan Game Theory}

Sehubungan dengan kampanye politik ketiga pasangan calon (pemain), Median melakukan survei melalui penyebaran kuesioner berdasarkan gender, domisili, usia, pendidikan, dan suku. Pada bagian ini hanya menyajikan satu contoh perhitungan teori permainan. Salah satu hasil kuesioner disajikan pada Tabel 1 (Median, 2017).

Tabel 1. Hasil Perolehan Kuesioner Median Berdasarkan Gender

\begin{tabular}{|c|c|c|c|c|c|c|c|}
\hline \multirow{2}{*}{$\begin{array}{c}\text { Strateg } \\
\text { ke- }\end{array}$} & \multirow{2}{*}{ Responden } & \multirow{2}{*}{$\begin{array}{l}\text { Basis } \\
(\%)\end{array}$} & \multicolumn{3}{|c|}{$\begin{array}{l}\text { Persentase responden } \\
\text { yang memilih } \\
\text { pemain }\end{array}$} & \multirow{2}{*}{$\begin{array}{l}\text { Tidak } \\
\text { Jawab } \\
(\%)\end{array}$} & \multirow{2}{*}{$\begin{array}{l}\text { Total } \\
(\%)\end{array}$} \\
\hline & & & $\begin{array}{c}A \\
(\%)\end{array}$ & $\begin{array}{l}\mathrm{B} \\
(\%)\end{array}$ & $\begin{array}{c}\mathrm{C} \\
(\%)\end{array}$ & & \\
\hline 1 & Responden laki-laki & 50,7 & 24,1 & 29,7 & 26,5 & 19,7 & 100 \\
\hline 2 & $\begin{array}{l}\text { Responden } \\
\text { perempuan }\end{array}$ & 49,3 & 28,2 & 30 & 29,3 & 12,5 & 100 \\
\hline & Total & 100 & & & & & \\
\hline
\end{tabular}

Berdasarkan Tabel 1, yang akan digunakan pada teori permainan hanya hasil pengisian kuesioner yang respondennya memilih salah satu calon. Oleh karena itu persentase responden yang tidak memberikan jawabannya tidak akan diperhitungkan. Misal untuk penjaringan responden berdasarkan gender, pemilih laki-laki basisnya $50,7 \%$ dari sampel dengan $19,7 \%$ bagiannya tidak menjawab. Dengan mengurangkan $19,7 \%$ dari pemilih laki-laki maka basis pemilih akan berkurang. Perhitungannya adalah sebagai berikut:

Basis baru pemilih laki-laki

$$
=50,7-(0,197 \times 50,7)=40,71
$$

Hal ini berarti basis pemilih laki-laki menjadi $40,71 \%$ dari sampel. Dari basis baru ini, ditentukan persentase distribusi pemilih terhadap masing-masing pemain.

Misal perolehan pemain A berdasarkan gender laki-laki dapat ditentukan dengan konsep perbandingan sebagai berikut:

$$
\frac{0,241 \times 50,7}{40,71} \times 100 \%=30,01 \%
$$

Dengan cara yang sama, maka diperoleh persentase yang memilih masing-masing pemain seperti yang tersaji pada Tabel 2 .

\begin{tabular}{|c|c|c|c|c|c|c|}
\hline \multirow{2}{*}{$\begin{array}{l}\text { Strategi } \\
\text { ke- }\end{array}$} & \multirow{2}{*}{ Strategi } & \multirow{2}{*}{$\begin{array}{c}\text { Basis } \\
(\%)\end{array}$} & \multicolumn{3}{|c|}{$\begin{array}{l}\text { Persentase yang } \\
\text { memilih pemain }\end{array}$} & \multirow{2}{*}{$\begin{array}{c}\text { Total } \\
(\%)\end{array}$} \\
\hline & & & $\begin{array}{c}\mathrm{A} \\
(\%)\end{array}$ & $\begin{array}{l}\mathrm{B} \\
(\%)\end{array}$ & $\begin{array}{c}\mathrm{C} \\
(\%)\end{array}$ & \\
\hline 1 & $\begin{array}{l}\text { Penjaringan pemilih } \\
\text { laki-laki }\end{array}$ & 40,71 & 30,01 & 36,99 & 33 & 100 \\
\hline 2 & $\begin{array}{l}\text { Penjaringan pemilih } \\
\text { perempuan }\end{array}$ & 43,14 & 32,23 & 34,28 & 33,49 & 100 \\
\hline & Total & 83,85 & & & & \\
\hline
\end{tabular}

Tabel 2. Nilai Pemain Berdasarkan Gender

Selanjutnya dihitung nilai pay off setiap pemain yang akan digunakan dalam matriks. Berdasarkan Tabel 2, diketahui bahwa basis pemilih laki-laki adalah 40,71 , hasil pengisian kuesioner pemain A sebesar $30,01 \%$ atau 0,3001 , dan total basis baru 83,85. Maka perolehan pemain A adalah

$$
\frac{0,3001 \times 40,71}{83,85} \times 100 \%=14,57 \%
$$

Dengan cara yang sama, maka didapat hasil perolehan bagi masing-masing pemain seperti yang tersaji pada Tabel 3 .

Tabel 3. Nilai Pemain Berdasarkan Gender

\begin{tabular}{|c|l|c|c|c|}
\hline \multirow{2}{*}{$\begin{array}{c}\text { Strategi } \\
\text { ke- }\end{array}$} & \multicolumn{1}{|c|}{ Strategi } & \multicolumn{3}{|c|}{$\begin{array}{c}\text { Nilai pay off Pemain } \\
\text { (Total 100\%) }\end{array}$} \\
\cline { 3 - 5 } & & $\mathrm{A}(\%)$ & $\mathrm{B}(\%)$ & $\mathrm{C}(\%)$ \\
\hline 1 & $\begin{array}{l}\text { Penjaringan pemilih } \\
\text { laki-laki }\end{array}$ & 14,57 & 17,96 & 16,02 \\
\hline 2 & $\begin{array}{l}\text { Penjaringan pemilih } \\
\text { perempuan }\end{array}$ & 16,58 & 17,64 & 17,23 \\
\hline
\end{tabular}


Tabel 3 menunjukkan nilai pay off bagi setiap pemain yang digunakan dalam perhitungan teori permainan. Bentuk mariks pay off dari permainan ini adalah seperti pada matriks (1) dengan $r=1,2 ; s=1,2$; dan $t=1$, 2.

Untuk menentukan nilai-nilai elemen matriks digunakan persamaan (1.1), (1.2), dan (1.3). Contoh perhitungan nilai pay off bagi pemain $\mathrm{A}$, pemain $\mathrm{B}$, dan pemain $\mathrm{C}$ secara berturut-turut dapat ditentukan sebagai berikut berdasarkan Tabel 3.

$$
\begin{aligned}
& a_{111}=14,57-\operatorname{maks}(17,96 ; 16,02)=-3,39 \\
& a_{112}=14,57-\operatorname{maks}(17,96 ; 17,23)=-3,39 \\
& a_{121}=14,57-\operatorname{maks}(17,64 ; 16,02)=-3,07 \\
& a_{122}=14,57-\operatorname{maks}(17,64 ; 17,23)=-3,07 \\
& a_{211}=16,58-\operatorname{maks}(17,96 ; 16,02)=-1,38 \\
& a_{212}=16,58-\operatorname{maks}(17,96 ; 17,23)=-1,38 \\
& a_{221}=16,58-\operatorname{maks}(17,64 ; 16,02)=-1,06 \\
& a_{222}=16,58-\operatorname{maks}(17,64 ; 17,23)=-1,06 \\
& b_{111}=17,96-\operatorname{maks}(14,57 ; 16,02)=1,93 \\
& b_{112}=17,96-\operatorname{maks}(14,57 ; 17,23)=0,73 \\
& b_{121}=17,64-\operatorname{maks}(14,57 ; 16,02)=1,62 \\
& b_{122}=17,64-\operatorname{maks}(14,57 ; 17,23)=0,41 \\
& b_{211}=17,96-\operatorname{maks}(16,58 ; 16,02)=1,38 \\
& b_{212}=17,96-\operatorname{maks}(16,58 ; 17,23)=0,73 \\
& b_{221}=17,64-\operatorname{maks}(16,58 ; 16,02)=1,06 \\
& b_{222}=17,64-\operatorname{maks}(16,58 ; 17,23)=0,41 \\
& c_{111}=16,02-\operatorname{maks}(14,57 ; 17,96)=-1,93 \\
& c_{112}=17,23-\operatorname{maks}(14,57 ; 17,96)=-0,73 \\
& c_{121}=16,02-\operatorname{maks}(14,57 ; 17,64)=-1,62 \\
& c_{122}=17,23-\operatorname{maks}(14,57 ; 17,64)=-0,41 \\
& c_{211}=16,02-\operatorname{maks}(16,58 ; 17,96)=-1,93 \\
& c_{212}=17,23-\operatorname{maks}(16,58 ; 17,96)=-0,73 \\
& c_{221}=16,02-\operatorname{maks}(16,58 ; 17,64)=-1,62 \\
& c_{222}=17,23-\operatorname{maks}(16,58 ; 17,64)=-0,41
\end{aligned}
$$

Berdasarkan bentuk umum matriks pay off (1) dan contoh perhitungan elemen matriks di atas diperoleh matriks pay off untuk permainan ini seperti yang tersaji pada matriks (2).

$$
\begin{aligned}
& A_{1} \quad C_{1} \quad C_{2} \\
& B_{1} \quad[(-3,39 ; 1,93 ;-1,93) \quad(-3,39 ; 0,73 ;-0,73) \\
& B_{2} \quad[(-3,07 ; 1,62 ;-1,62) \quad(-3,07 ; 0,41 ;-0,41)] \\
& \begin{array}{lcc}
A_{2} & C_{1} & C_{2} \\
B_{1} \\
B_{2}
\end{array} \quad\left[\begin{array}{cc}
(-1,38 ; 1,38 ;-1,93) & (-1,38 ; 0,73 ;-0,73) \\
(-1,06 ; 1,06 ;-1,62) & (-1,06 ; 0,41 ;-0,41)
\end{array}\right]
\end{aligned}
$$

Dari matriks (2), selanjutnya ditentukan strategi optimal bagi setiap pemain. Strategi optimal dapat ditentukan menggunakan konsep ekuilibrium Nash. Pertama, dilakukan pengujian keberadaan titik ekuilibrium menggunakan konsep ekuilibrium Nash murni. Diuji respon terbaik bagi setiap pemain dengan membandingkan nilai pay off tiap strategi suatu pemain. Strategi yang memberikan nilai maksimal adalah strategi terbaik untuk digunakan oleh pemain.

Sebagai contoh pada matriks pay off (2), untuk pemain $\mathrm{A}$, jika pemain $\mathrm{B}$ dan $\mathrm{C}$ menggunakan strategi 1, maka pada strategi $\left(A_{1}\right.$, $\left.B_{1}, C_{1}\right)$ dan $\left(A_{2}, B_{1}, C_{1}\right)$ yang secara berturutturut memiliki nilai pay off $(-3,39 ; 1,93 ;-19,3)$ dan $(-1,38 ; 1,38 ;-1,93)$, nilai $-1,38$ pada elemen $\left(A_{2}, B_{1}, C_{1}\right)$ merupakan nilai maksimal pada komponen pertama, maka $A_{2}$ merupakan strategi terbaik yang disarankan bagi pemain $\mathrm{A}$.

Kemudian pay off bagi pemain B dapat dilihat pada komponen kedua dari setiap kolom matriks. Jika pemain A dan C menggunakan strategi 1 maka pada nilai pay off $(-3,39 ; 1,93$; $1,93)$ dan $(-3,07 ; 1,62 ;-1,62)$, nilai 1,93 pada elemen $\left(A_{1}, B_{1}, C_{1}\right)$ merupakan nilai maksimal dari komponen kedua, sehingga $B_{1}$ merupakan strategi terbaik yang disarankan bagi pemain $B$.

Dengan cara yang sama, strategi terbaik yang disarankan bagi pemain $\mathrm{C}$ dapat dilihat pada komponen ketiga dari setiap baris. Jika pemain $\mathrm{A}$ dan $\mathrm{B}$ menggunakan strategi 1, maka nilai $-0,73$ pada elemen $\left(A_{1}, B_{1}, C_{2}\right)$ merupakan nilai maksimal pada komponen ketiga, sehingga $C_{2}$ merupakan strategi terbaik yang disarankan bagi pemain $\mathrm{C}$.

Titik ekuilibrium Nash adalah kondisi dimana setiap komponen pay off pada satu set strategi merupakan respon terbaik bagi semua pemain. Hasil pengujian respon terbaik ketiga pemain berdasarkan matriks pay off (2) dapat disajikan seperti pada matriks (3)

$$
\begin{aligned}
& A_{1} \quad C_{1} \quad C_{2} \\
& B_{1} \quad\left[\left(-3,39 ; 1,93^{*} ;-1,93\right) \quad\left(-3,39 ; 0,73^{*} ;-0,73^{*}\right)\right. \\
& B_{2} \quad[(-3,07 ; 1,62 ;-1,62) \quad(-3,07 ; 0,41 ;-0,41)] \\
& \begin{array}{ccc}
A_{2} & C_{1} & C_{2} \\
B_{1} & {\left[\left(-1,38^{*} ; 1,38^{*} ;-1,93\right)\right.} & \left(-1,38^{*} ; 0,73^{*} ;-0,73^{*}\right)
\end{array} \\
& \left.B_{2} \quad\left(-1,06^{*} ; 1,06 ;-1,62\right) \quad\left(-1,06^{*} ; 0,41 ;-0,41^{*}\right)\right]
\end{aligned}
$$

Hal ini berarti pada pengujian tersebut diperoleh titik ekuilibrium Nash. Strategi terbaik yang disarankan bagi setiap pemain adalah set strategi $\left(A_{2}, B_{1}, C_{2}\right)$ dengan nilai pay off $(-1,38$; $0,73 ;-0,73)$ yang merupakan titik ekuilibrium 
murni Nash sebagai strategi optimal bagi semua pemain. Strategi optimal terjadi jika pemain A memainkan strategi $A_{2}$, pemain $\mathrm{B}$ memainkan strategi $B_{1}$, dan pemain $C$ memainkan strategi $C_{2}$.

Pada pemain A, ekuilibrium murni Nash terjadi ketika nilai pay off $-1,38$. Hal ini menunjukkan kemungkinan terburuk bagi pemain A akan mengalami ketertinggalan perolehan suara maksimal sebesar $1,38 \%$ dari pemain $\mathrm{B}$ yang menggunakan strategi $B_{1}$ dan pemain $\mathrm{C}$ yang menggunakan strategi $C_{2}$. Pada pemain $\mathrm{B}$, ekuilibrium murni Nash terjadi ketika pay off 0,73 . Hal ini menunjukkan kemungkinan terburuk bagi pemain $\mathrm{B}$ akan mengalami keunggulan perolehan suara minimum sebesar $0,73 \%$ dari pemain A dengan strategi $A_{2}$ dan pemain $\mathrm{C}$ dengan strategi $C_{2}$. Pada pemain $\mathrm{C}$, ekuilibrium murni Nash terjadi ketika pay off 0,73 yang berarti kemungkinan terburuk bagi pemain $\mathrm{C}$ akan mengalami ketertinggalan perolehan suara maksimum sebesar $0,73 \%$ dari pemain A yang menggunakan strategi $A_{2}$ dan pemain B yang menggunakan strategi $B_{1}$.

Persentase ekpektasi pay off pada strategi optimal di atas adalah berdasarkan basisnya masing-masing. Untuk mengetahui persentase berdasarkan seluruh responden, maka dapat dilakukan perhitungan seperti berikut.

Misal pemain A memiliki kemungkinan terburuk akan mendapat suara $1,38 \%$ lebih rendah dari pemain lain dengan $83,85 \%$ merupakan basis pemilih berdasarkan gender. Jika basisnya $100 \%$, maka ekspektasi pay off pemain A menjadi:

$$
\frac{-1,38 \% \times 100 \%}{83,85 \%}=-1,65 \%
$$

Ekspektasi pay off dari semua strategi optimal pada permainan ini juga dapat ditentukan dengan cara yang sama.

\subsection{Nilai Expected Pay Off dan Strategi Optimal Tiap Pemain}

Dari titik ekuilibrium murni Nash tersebut maka didapat strategi optimal bagi setiap pemain, yaitu:
Dari titik ekuilibrium murni Nash tersebut maka didapat strategi optimal bagi setiap pemain, yaitu:

\section{a. Strategi Penjaringan Pemilih berdasarkan Gender}

Pada matriks pay off berdasarkan gender, titik ekuilibrium murni Nash terletak pada titik $\left(A_{2}, B_{1}, C_{2}\right)$ dengan nilai pay off $(-1,65 ; 0,87$; $0,87)$. Titik ekuilibrium terjadi jika pemain A menggunakan strategi penjaringan pemilih perempuan, pemain $\mathrm{B}$ menggunakan strategi penjaringan pemilih laki-laki, dan pemain $\mathrm{C}$ menggunakan strategi penjaringan pemilih perempuan. Hal ini berarti jika pemain A menggunakan strategi ekuilibrium maka kemungkinan terburuk baginya adalah akan mengalami ketertinggalan suara maksimal $1,65 \%$ dari pemain lain. Selanjutnya jika pemain B menggunakan strategi ekuilibrium maka kemungkinan terburuk baginya adalah akan memperoleh keunggulan suara minimal $0,87 \%$ dari pemain lain. Lebih lanjut lagi, jika pemain $\mathrm{C}$ menggunakan strategi ekuilibrium maka kemungkinan terburuk baginya adalah akan mengalami ketertinggalan suara maksimal $0,87 \%$ dari pemain lain.

\section{b. Strategi Penjaringan Pemilih berdasarkan Domisili}

Pada matriks pay off berdasarkan domisili, titik ekuilibrium murni Nash terletak pada titik $\left(A_{4}, B_{1}, C_{4}\right)$ dengan nilai pay off ($1,03 ; 0,13 ;-0,13)$. Titik ekuilibrium terjadi jika pemain A menggunakan strategi penjaringan pemilih berdomisili Jakarta Timur, pemain B menggunakan strategi penjaringan pemilih berdomisili Jakarta Barat, dan pemain C menggunakan strategi penjaringan pemilih berdomisili Jakarta Timur. Hal ini berarti jika pemain A menggunakan strategi ekuilibrium maka kemungkinan terburuk baginya adalah akan mengalami ketertinggalan suara maksimal $1,03 \%$ dari pemain lain. Selanjutnya jika pemain B menggunakan strategi ekuilibrium maka kemungkinan terburuk baginya adalah akan memperoleh keunggulan suara minimal 0,13\% dari pemain lain. Lebih lanjut lagi, jika pemain C menggunakan strategi ekuilibrium maka 
kemungkinan terburuk baginya adalah akan mengalami ketertinggalan suara maksimal $0,13 \%$ dari pemain lain.

\section{c. Strategi Penjaringan Pemilih berdasarkan Usia}

Pada matriks pay off berdasarkan usia, titik ekuilibrium murni Nash terletak pada titik $\left(A_{2}\right.$, $\left.B_{2}, C_{2}\right)$ dengan nilai pay off $(-3,94 ;-1,8 ; 1,8)$. Titik ekuilibrium terjadi jika semua pemain memaksimalkan strategi penjaringan pemilih usia 20 - 29 tahun. Hal ini berarti jika pemain A menggunakan strategi ekuilibrium maka kemungkinan terburuk baginya adalah akan mengalami ketertinggalan suara maksimal 3,94\% dari pemain lain. Selanjutnya jika pemain B menggunakan strategi ekuilibrium maka kemungkinan terburuk baginya adalah akan mengalami ketertinggalan suara maksimal 1,8\% dari pemain lain. Lebih lanjut lagi, jika pemain C menggunakan strategi ekuilibrium maka kemungkinan terburuk baginya adalah akan memperoleh keunggulan suara minimal 1,8\% dari pemain lain.

d. Strategi Penjaringan Pemilih berdasarkan Tingkat Pendidikan

Pada matriks pay off berdasarkan tingkat pendidikan, titik ekuilibrium murni Nash terletak pada titik $\left(A_{4}, B_{4}, C_{4}\right)$ dengan nilai pay off $(-1,6 ;-0,16 ; 0,16)$. Titik ekuilibrium terjadi jika semua pemain memaksimalkan strategi penjaringan pemilih lulusan SMU/SMK. Hal ini berarti jika pemain A menggunakan strategi ekuilibrium maka kemungkinan terburuk baginya adalah akan mengalami ketertinggalan suara maksimal $1,6 \%$ dari pemain lain. Selanjutnya jika pemain B menggunakan strategi ekuilibrium maka kemungkinan terburuk baginya adalah akan mengalami ketertinggalan suara maksimal $0,16 \%$ dari pemain lain. Lebih lanjut lagi, jika pemain $\mathrm{C}$ menggunakan strategi ekuilibrium maka kemungkinan terburuk baginya adalah akan memperoleh keunggulan suara minimal $0,16 \%$ dari pemain lain.

\section{e. Strategi Penjaringan Pemilih berdasarkan Suku}

Pada matriks pay off berdasarkan suku, titik ekuilibrium murni Nash terletak pada titik $\left(A_{1}\right.$, $\left.B_{1}, C_{1}\right)$ dengan nilai pay off $(-0,93 ;-0,16 ; 0,93)$. Titik ekuilibrium terjadi jika semua pemain memaksimalkan strategi penjaringan pemilih dari komunitas/suku Jawa. Hal ini berarti jika pemain A menggunakan strategi ekuilibrium maka kemungkinan terburuk baginya adalah akan mengalami ketertinggalan suara maksimal $0,93 \%$ dari pemain lain. Selanjutnya jika pemain B menggunakan strategi ekuilibrium maka kemungkinan terburuk baginya adalah akan mengalami ketertinggalan suara maksimal 0,16\% dari pemain lain. Lebih lanjut lagi, jika pemain $\mathrm{C}$ menggunakan strategi ekuilibrium maka kemungkinan terburuk baginya adalah akan memperoleh keunggulan suara minimal $0,93 \%$ dari pemain lain.

\section{KESIMPULAN DAN SARAN}

\subsection{Kesimpulan}

Berdasarkan pembahasan pada bab III, dapat ditarik kesimpulan sebagai berikut:

1. Nilai ekspektasi pay off pada strategi optimal permainan ini adalah sebagai berikut:

a. Pada strategi penjaringan pemilih berdasarkan gender, nilai ekspektasi pasangan calon $(\mathrm{A}, \mathrm{B}, \mathrm{C})$ adalah $(-1,65$; $0,87 ;-0,87)$.

b. Pada strategi penjaringan pemilih berdasarkan domisili, nilai ekspektasi pasangan calon $(\mathrm{A}, \mathrm{B}, \mathrm{C})$ adalah $(-1,03$; $0,13 ;-0,13)$.

c. Pada strategi penjaringan pemilih berdasarkan usia, nilai ekspektasi pasangan calon (A, B, C) adalah (-3,94; $1,8 ;-1,8)$.

d. Pada strategi penjaringan pemilih berdasarkan tingkat pendidikan, nilai ekspektasi pasangan calon $(\mathrm{A}, \mathrm{B}, \mathrm{C})$ adalah $(-1,6 ;-0,16 ; 0,16)$.

e. Pada strategi penjaringan pemilih berdasarkan suku, nilai ekspektasi 
pasangan calon $(\mathrm{A}, \mathrm{B}, \mathrm{C})$ adalah $(-0,93$; $1,6 ; 0,93)$.

2. Strategi ekuilibrium untuk memperoleh suara optimal dalam pemilukada DKI Jakarta tahun 2017 dengan konsep teori permainan adalah:

a. Untuk pasangan A dapat memfokuskan pada strategi penjaringan pemilih perempuan, pemilih yang berdomisili di Jakarta Timur, pemilih berusia $20-29$ tahun, pemilih lulusan SMU/SMK, dan pemilih dari komunitas/suku Jawa.

b. Untuk pasangan B dapat memfokuskan pada strategi penjaringan pemilih lakilaki, pemilih yang berdomisili di Jakarta Barat, pemilih berusia $20-29$ tahun, pemilih lulusan SMU/SMK, dan pemilih dari komunitas/suku Jawa.

c. Untuk pasangan $\mathrm{C}$ dapat memfokuskan pada strategi penjaringan pemilih perempuan, pemilih yang berdomisili di Jakarta Timur, pemilih berusia $20-29$ tahun, pemilih lulusan SMU/SMK, dan pemilih dari komunitas/suku Jawa.

\subsection{Saran}

Bagi yang akan melanjutkan pembahasan mengenai penerapan teori permainan berjumlah tak nol pada tiga pemain, disarankan untuk menambah jumlah strategi dan menggunakan permainan yang memungkinkan adanya koalisi antarpemain (cooperative game).

\section{DAFTAR PUSTAKA}

Charmichael, Fiona. (2005). A Guide to Game Theory. [E-book]. Tersedia : https://lythuyettrochoi.wikispaces.com/file/vi ew/A+Guide+to+Game+Theory.pdf. Diakses 15 Februari 2017 pukul 11.33 WITA.

Hendri, Jhon. 2009. Riset Operasional. Depok: Universitas Gunadarma.

Median. 2017. Nasional Press Release Survei PILKADA DKI Jan - Feb 2017. [Online] Available at: www.meian.or.id/wp-content /upload /2017/02/RILIS-SURVEI - MEDIAN -BUMBU - DESA - CIKINI - 6 - FEB 2017.pdf

Mustaqim, Kiki. 2013. Aplikasi Konsep Teori Permainan dalam Pengambilan Keputusan Politik. Skripsi. Bandung: UPI.

Ririez. 2011. Teori Permainan. http://ririez.blog.uns.ac.id/. Diakses pada tanggal 20 November 2016 pukul 06.08 WITA.

Septiyani, H.I. 2007. Analisis Teori Permainan dan Ekuilibrium Nash pada Simulasi Lenag (Auction) Pasar Listrik. Skripsi. Bandung: ITB.

Simamora, C.H., Rosmiani, E., and Napitupulu, N. 2013. Penerapan Teori Permainan dalam Pemasaran Produk Ban Sepeda Motor di FMIPA USU. Saintia Matematika, 1(2), pp $129-137$. 